\title{
Analisis Bakteriologis Air Minum Isi Ulang di Kecamatan Ratolindo, Kabupaten Tojo Una-Una
}

\author{
Hasanah $^{* 1}{ }^{1}$ Pitriani $^{1}$, Nur rizka ${ }^{1}$, Nurdin $^{2}$ \\ ${ }^{1}$ Departemen Kesehatan Lingkungan, Fakultas Kesehatan Masyarakat, Universitas \\ Tadulako \\ ${ }^{2}$ Departemen Gizi, Fakultas Kesehatan Masyarakat, Universitas Tadulako
}

Author's Email Correspondence (*): hasanah_biomed@yahoo.co.id

$(+6282187076964)$

\begin{abstract}
ABSTRAK
Salah satu indikator yang digunakan untuk air minum yang aman untuk kesehatan adalah bakteriologi. Air minum yang aman adalah air yang tidak mengandung Escherichia coli dan/atau total bakteri coliform. Sehingga adanya Escherichia coli dan/atau total bakteri coliform dalam air minum menunjukkan bahwa dalam air minum telah terkontaminasi cemaran bakteriologi. Tujuan dari penelitian ini untuk Menganalisis bakteriologis air minum isi ulang di Kecamatan Ratolindo, Kabupaten Tojo Una-Una. Penelitian ini bersifat deskriptif dengan pendekatan uji laboratorium, hasil disajikan dalam bentuk tabel dan narasi. Sampel air minum dalam penelitian ini diambil di 11 depot air minum isi ulang secara composite sampel by time. Hasil pemeriksaan kadar Escherichia coli pada sampel air minum isi ulang menunjukkan bahwa seluruh depot memenuhi syarat sedangkan pemeriksaan kadar total bakteri coliform terdapat 3 depot tidak memenuhi syarat kualitas air minum sesuai dengan permenkes no. 492/MENKES/PER/IV/2010. Hygiene sanitasi DAM dilihat dari aspek Tempat sebanyak 10 depot $(90,9)$ memenuhi syarat dan 1 depot $(9,1)$ tidak memenuhi syarat, aspek peralatan sebanyak 11depot $(100)$ memenuhi syarat dan 0 depot (0) tidak memenuhi syarat, aspek penjamah sebanyak 4 depot $(36,4)$ memenuhi syarat dan 7 depot $(63,6)$ tidak memenuhi syarat, aspek air minum sebanyak 10 depot $(90,90)$ memenuhi syarat dan 1 depot $(9,10)$ tidak memenuhi syarat.
\end{abstract}

Kata Kunci: Depot Air minum isi ulang; Escherichia coli; Coliform; Hygiene sanitasi

Published by:

Tadulako University

Address:

Jl.Soekarno Hatta KM 9. Kota Palu, Sulawesi Tengah, Indonesia.

Phone: +628114120202

Email: Preventif.fkmuntad@gmail.com
Article history :

Received : 26112021

Received in revised form : 01122021

Accepted : 25122021

Available online 21122021 


\begin{abstract}
Bacteriology is one of the indicators used for safe drinking water for health. Safe drinking water is water that does not contain Escherichia coli and/or total coliform bacteria. So the presence of Escherichia coli and/or total coliform bacteria in drinking water indicates that the drinking water has been contaminated with bacteriological contamination. The research aims to analyze the bacteriology of refill drinking water in Ratolindo Sub-District, Tojo Una-Una District. This was a descriptive with a laboratory test approach which result presented in the form of tables and narratives. The drinking water samples in this research were taken from 11 refill drinking water depots using a composite sample by time. The results of the examination of Escherichia coli levels in refill drinking water samples showed that all depots met the requirements, while the examination of total coliform bacteria levels contained 3 depots that did not meet the drinking water quality requirements according to the Minister of Health no. 492/MENKES/PER/IV/2010. Hygiene sanitation of DAM seen from the aspect of place as many as 10 depots (90.9) meet the requirements and 1 depot (9.1) does not meet the requirements, equipment aspect as many as 11 depots (100) meet the requirements and 0 depots $(0)$ do not meet the requirements, 4 depots (36.4) meet the requirements and 7 depots (63.6) do not meet the requirements, 10 depots (90.90) meet the requirements and 1 depot $(9,10)$ is not eligible.
\end{abstract}

Keywords : Refill drinking water depot; Escherichia coli; Coliform; Sanitary Hygiene

\title{
PENDAHULUAN
}

Air minum isi ulang adalah salah satu jenis air minum yang dapat langsung diminum tanpa dimasak terlebih dahulu, karena telah mengalami proses pemurnian baik secara penyinaran ultraviolet, ozonisasi, ataupun keduannya. Pada era sekarang ini kesadaran masyarakat untuk mendapatkan air yang memenuhi syarat kesehatan semakin meningkat. Seiring dengan hal tersebut maka dewasa ini semakin menjamur pula depot air minum (DAM) yang menyediakan air siap minum (1).

Usaha DAM merupakan salah satu bisnis skala kecil dan menengah yang berkontribusi terhadap penyediaan air minum dengan harga terjangkau namun Perkembangan usaha depot air minum isi ulang dapat juga berpotensi menimbulkan dampak negatif terhadap kesehatan konsumen bila tidak ada regulasi yang efektif (2).

Menurut (Peraturan menteri kesehatan Nomor 492/MENKES/PER/IV 2010) secara mikrobiologis, air minum yang sehat harus bebasdari bakteri Esherichia coli dan total bakteri coliform. Beberapa patogen yang ditularkan melalui air minum yang tercemar dapat menyebabkan penyakit yang parah hingga menyebabkan kematian (3). Contohnya yaitu tifus,kolera, hepatitis menular (disebabkan oleh virus hepatitis A atau virus hepatitis E) dan penyakit yang disebabkan oleh Shigella spp dan Esherichia coli seperti penyakit diare (4). 
Menurut WHO sebanyak 1,9 juta anak balita yang meninggal karena penyakit diare diantara 2 milyar kasus yang terjadi di seluruh dunia dalam setiap tahun, dan $78 \%$ kasus kematian terjadi di wilayah Afrika dan Asia Tenggara. Berdasarkan data (Kementrian kesehatan RI 2018) pada tahun 2017 penderita diare semua umur sebanyak 4.274.790 penderita atau 60,4\% (5). Berdasarkan (Dinas Kesehatan Kabupaten Tojo Una-Una 2020) penderita diare di Kabupaten Tojo Una-una tahun 2019 sebanyak 1.012 penderita diare pada balita dan 2.935 penderita diare semua umur. Beberapa faktor penyebab timbulnya penyakit diare disebabkan oleh kuman melalui kontaminasi makanan atau minuman yang tercemar tinja dari faktor resiko lainnya yaitu faktor penjamin dan faktor lingkungan (6).

Setiap depot air minum isi ulang harus menerapkan aturan sesuai dengan (Peraturan Menteri Kesehatan Nomor 492/MENKES/PER/IV 2010) tentang persyaratan kualitas air minum baik parameter fisika, kimia maupun biologi. Diberbagai negara khusunnya negara maju lebih menekankan pada standar kimia sedangkan dinegara berkembang lebih menekankan pada standar biologi (7).

Seiring dengan majunya teknologi diiringi dengan semakin banyaknya aktivitas masyarakat cenderung akan memilih cara yang lebih praktis dengan biaya yang relatif murah dalam memenuhi kebutuhan air minum termasuk di Kecamatan Ratolindo, Kabupaten Tojo Una-una. Kebutuhan air minum di masyarakat terus meningkat sementara masyarakat semakin sulit mendapatkan air minum dengan kualitas baik yang berasal dari air tanah maupun air dari Perusahaan Daerah Air Minum (PDAM), sehingga salah satu pemenuhan kebutuhan air minum yang menjadi alternatif yaitu dengan menggunakan air minum isi ulang.

Berdasarkan data Dinas Kesehatan Provinsi Sulawesi Tenggah 2020)di Kabupaten Tojo Una-una tahun 2019 terdapat 54 depot air minum dan data (Dinas Kesehatan Kabupaten Tojo Una-Una 2020) dari 12 kecamatan yang terdapat di Kabupaten Tojo Una-una, Kecamatan Ratolindo adalah wilayah yang memiliki DAM terbanyak yaitu 11 depot air minum (8).

Dengan adannya depot air minum isi ulang masyarakat tetap diharapkan selalu waspada terhadap kemungkinan adanya bahaya mikroorganisme terutama bakteri yang terkandung dalam produk air minum. Kehadiran bakteri Coliform dalam air minum menjadi salah satu parameter biologis kualitas air minum. Semakin tinggi tingkat kontaminasi bakteri Coliform, Maka semakin tinggi pula risiko gangguan kesehatan. Untuk mengetahui sejauh mana air telah terkontaminasi oleh bahan buangan organisme, maka perlu dilakukan identifikasi bakteri Coliform dan Esherichia coli untuk mengetahui kualitas air minum isi ulang yang di 
konsumsi layak atau tidak digunakan masyarakat di Kecamatan Ratolindo, Kabupaten Tojo Una-una sebagai air untuk minum.

Melalui penelitian ini, peneliti tertarik menganalisis kandungan Escherichia coli dan bakteri coliform air minum isi ulang dikarenakan belum adanya penelitan tentang kualitas air minum isi ulang di Kabupaten Tojo Una-una yang beredar khususnya di Kecamatan Ratolindo.

\section{METODE}

Penelitian ini bersifat deskriptif dengan pendekatan uji laboratorim. Penelitian ini mengambil sampel pada 11 depot air minum isi ulang di wilayah Kecamatan Ratolindo, Kabupaten Tojo Una-Una. Pengambilan sampel dilakukan menggunakan peralatan yang steril dengan Teknik pengambilan sampel gabungan waktu (composite sample by time), yaitu sampel yang diambil dari waktu yang berbeda dengan volume yang sama. Sampel yang diambil mewakili semua metode pengolahan DAM yaitu metode UV, ozon atau reverse osmosis (RO). Pengujian sampel air minum dilakukan menggunakan metode Most ProbableNumber (MPN) berupa pengukuran kandungan bakteriologis air minum isi ulang yang dilakukan di Laboratorium Dinas Kesehatan Kabupaten Tojo Una-Una pada bulan november-desember 2020. Pengambilan data hygiene sanitasi dilakukan menggunakan quesioner terstruktur.

\section{HASIL}

Kualitas Bakteriologis Air Minum pada Depot Air Minum di Kecamatan Ratolindo Kabupaten Tojo Una-una 
Tabel 1

Distribusi Bakteriologis Air Minum pada Depot Air Minum di Kecamatan

Ratolindo Kabupaten Tojo Una-Una

\begin{tabular}{|c|c|c|c|c|c|c|c|}
\hline \multirow[t]{4}{*}{ NO } & \multirow[t]{4}{*}{ Nama depot } & \multirow[t]{3}{*}{ Metode } & \multirow{3}{*}{$\begin{array}{c}\text { Sumber air } \\
\text { baku }\end{array}$} & \multicolumn{2}{|c|}{ Parameter } & \multirow{2}{*}{\multicolumn{2}{|c|}{$\begin{array}{r}\text { Memenuhi } \\
\text { syarat }\end{array}$}} \\
\hline & & & & Escherichia coli & Coliform & & \\
\hline & & & & MPN/100 ml & MPN/100 ml & Ya & Tidak \\
\hline & & $\mathrm{RO}$ & Sumur suntik & 0 & & $\checkmark$ & \\
\hline \multirow[t]{2}{*}{1.} & Depot 1 & Ozon & & 0 & 0 & $\checkmark$ & \\
\hline & & UV & & 0 & 0 & $\checkmark$ & \\
\hline \multirow[t]{2}{*}{2.} & Depot 2 & $\mathrm{RO}$ & PDAM & 0 & 0 & $\checkmark$ & \\
\hline & & Ozon & & 0 & 0 & $\checkmark$ & \\
\hline \multirow[t]{3}{*}{3.} & Depot 3 & $\mathrm{RO}$ & Sumur suntik & 0 & 0 & $\checkmark$ & \\
\hline & & Ozon & & 0 & 0 & $\checkmark$ & \\
\hline & & UV & & 0 & 0 & $\checkmark$ & \\
\hline \multirow[t]{2}{*}{4.} & Depot 4 & RO & Sumur suntik & 0 & 39 & & $\checkmark$ \\
\hline & & Ozon & & 0 & 3 & & $\checkmark$ \\
\hline \multirow[t]{3}{*}{5.} & Depot 5 & RO & Sumur suntik & 0 & 0 & $\checkmark$ & \\
\hline & & Ozon & & 0 & 0 & $\checkmark$ & \\
\hline & & UV & & 0 & 0 & $\checkmark$ & \\
\hline \multirow[t]{2}{*}{6.} & Depot 6 & RO & Sumur suntik & 0 & 0 & $\checkmark$ & \\
\hline & & Ozon & & 0 & 0 & $\checkmark$ & \\
\hline \multirow[t]{3}{*}{7.} & Depot 7 & RO & Sumur suntik & 0 & 0 & $\checkmark$ & \\
\hline & & Ozon & & 0 & 0 & $\checkmark$ & \\
\hline & & UV & & 0 & 0 & $\checkmark$ & \\
\hline \multirow[t]{2}{*}{8.} & Depot 8 & $\mathrm{RO}$ & Sumur suntik & 0 & 0 & $\checkmark$ & \\
\hline & & Ozon & & 0 & 25 & & $\checkmark$ \\
\hline \multirow[t]{2}{*}{9.} & Depot 9 & $\mathrm{RO}$ & Sumur suntik & 0 & 0 & $\checkmark$ & \\
\hline & & Ozon & & 0 & 0 & $\checkmark$ & \\
\hline 10. & Depot 10 & RO & PDAM & 0 & 0 & $\checkmark$ & \\
\hline 11. & Depot 11 & UV & Sumur suntik & 0 & 11 & & $\checkmark$ \\
\hline
\end{tabular}

Sumber: Data Primer, 2020

Tabel 1 menunjukkan bahwa asal sumber air baku yang digunakan depot air minum isi ulang di Kecamatan Ratolindo berasal dari sumur suntik sebanyak 9 depot, dan dari PDAM sebanyak 2 depot. Dengan metode pengelolaan ultraviolet (UV), ozonisasi menggunakan $\mathrm{O} 3$ dan reverse osmosis (RO).

Tabel 2

Distribusi Frekuensi Kondisi Higiene sanitasi Depot Air Minum di Kecamatan Ratolindo Kabupaten Tojo Una-Una

\begin{tabular}{cccccccc}
\hline NO & Higiene sanitasi & \multicolumn{4}{c}{ Memenuhi syarat } & \multicolumn{2}{c}{ Total } \\
\cline { 3 - 6 } & & \multicolumn{3}{c}{ Ya } & Tidak & & \\
& & $\mathbf{n}$ & $\mathbf{\%}$ & $\mathbf{n}$ & $\mathbf{\%}$ & $\mathbf{n}$ & $\mathbf{\%}$ \\
1 & Tempat & 10 & 90,9 & 1 & 9,1 & 11 & 100 \\
2 & Peralatan & 11 & 100 & 0 & 0 & 11 & 100 \\
3 & Penjamah & 4 & 36,4 & 7 & 63,6 & 11 & 100 \\
4 & Air Minum & 10 & $90,90 \%$ & 1 & $9,10 \%$ & 11 & 100 \\
\hline
\end{tabular}

Sumber: Data Primer, 2020 


\section{PEMBAHASAN}

\section{Kualitas Bakteriologis Air Minum pada Depot Air Minum di Kecamatan Ratolindo Kabupaten Tojo Una-una}

Kualitas bakteriologis air minum isi ulang di Kecamatan Ratolindo Kabupaten Tojo Una-Una berdasarkan uji laboratorium dapat dilihat pada tabel 1 menunjukan bahwa terdapat 3 depot air minum dengan sumber air baku berasal dari sumur suntik terdapat kandung bakteri coliform hal tersebut tidak memenuhi syarat kualitas air minum sesuai dengan Peraturan Menteri Kesehatan Republik Indonesia NO.492/MENKES/PER/IV/2010 (9).

Sumur suntik merupakan salah satu sumber air baku yang digunakan DAM di Kecamatan Ratolindo, berdasarkan tabel 1 didapatkan hasil bahwa semua yang mengandung coliform bersumber dari air sumur suntik hal ini dapat disebabkan karena terjadinya cemaran pada air tanah. Cemaran ini dapat berasal dari buangan air cucian kamar mandi, air tinja/rembesan dari septic tank, maupun buangan sampah dari aktivitas masyarakat. Akan tetapi sumber air baku yang berasal dari PDAM tidak ditemukan adanya cemaran bakteriologi pada air minum isi ulang yang dihasilkan hal ini dikarenakan air baku dari PDAM telah dilakukan pengolahan terlebih dahulu dengan cara klorinasi.

Faktor lain yang mempengaruhi kualitas air minum Kecamatan Ratolindo yaitu bangunan yang digunakan kurang terawat dan kondisi hygiene sanitasi depot air minum yang belum memenuhi syarat. Sepeti tidak tersedianya tempat sampah yang tertup, tidak terdapat tempat cuci tanggan yang dilengkapi air mengalir dan sabun, terdapat 2 depot air minum yang memiliki lantai tidak rata dan keramik yang pecah-pecah, pekerja yang tidak berperilaku hygiene seperti tidak mecuci tanggan dan menggunakan pakaian kerja yang bersih dan rapi saat melayani konsumen serta terdapat depot dengan dinding bangunanya hanya menggunakan pagar besi sehinga sangat mudah masuknya debu dan hewan-hewan lain.

Dalam Peraturan Menteri Kesehatan Republik Indonesia NO.492/MENKES/PER/IV/2010 tersebut menyebutkan bahwa tidak boleh adanya total bakteri coliform ataupun Escherichia coli pada air minum. Kualitas bakteriologis pada air minum yang diproduksi oleh depot air minum dapat dipengaruhi oleh sumber air baku yang digunakan, tempat atau lokasi depot air minum, peralatan, penjamah maupun prosedur pengolahan air tersebut. Hal ini sesuai dengan pedoman inspeksi depot air minum dari Permenkes RI NO. 43 Tahun 2014 tentang higiene sanitasi depot Air minum (10).

Hal ini sesuai dengan penelitian yang menunjukan bahwa tidak semua air minum hasil 
produksi depot air minum yang ada di wilayah kerja puskesmas dahlia kota makassar memenuhi syarat kualitas air minum. Hasil penelitian menunjukan bahwa dari 22 sampel air minum isi ulang terdapat 20 sampel air minum isi ulang yang memenuhi syarat dan 2 sampel air minum isi ulang yang tidak memenuhi syarat. Dengan adanya masalah tersebut perlu adanya pengawasan dari Dinas Kesehatan terhadap depot air minum serta adanya pembinaan dari pemerintah setempat untuk pengelola depot air minum terhadap kualitas bakteriologis yang sesuai baku mutu yang ditetapkan (11).

Pengelolaan air minum isi ulang yang kurang hygiene dapat beresiko terjadinya kontaminasi air minum dari berbagai mikroorganisme terutama bakteri coliformdan Escherichia coli yang dapat menyebabkan gangguan kesehatan. Coliform merupakan cakupan organisme yang dapat bertahan dan bekembang dalam air. Dengan demikian coliform dapat digunakan sebagai indikator keefektifan pengolahan dan untuk mengkaji kebersihan dan integritas distribusi serta keberadaan potensial biofilm. Oleh karena itu, adanya bakteri coliform di dalam makanan atau minuman menunjukkan adanya mikroorganisme pathogen. Semakin tinggi kontaminasi bakteri coliform dalam air, semakin tinggi pula resiko kehadiran bakteri-bakteri patogen lain yang biasa hidup dalam kotoran hewan ataupun manusia seperti salmonella, shigella dan staphylococcus. Keberadaannya dalam jumlah tinggi berkemungkinan pertumbuhan dari Salah satu contoh bakteri patogen yang kemungkinan dapat terkontaminasi kotoran manusia atau hewan dalam air adalah bakteri Escherichia coli (11).

\section{Hygiene Sanitasi Depot Air Minum di Kecamatan Ratolindo Kabupaten Tojo Una-una Kondisi Hygiene Sanitasi Tempat}

Berdasarkan hasil observasi dan wawancara pada tabel 2 kondisi hygiene sanitasi depot air minum yang ada di Kecamatan Ratolindo dari 11 depot air minum di dapatkan hasil bahwa dari segi aspek tempat sebanyak 1 depot air minum $(9,1 \%)$ tidak memenuhi syarat dan 10 depot depot air minum $(90,9 \%)$ memenuhi syarat. hal ini dikarenakan tidak tersedianya tempat cuci tanggan yang dilengkapi degan air mengalir dan sabun, tidak terdapat tempat sampah yang tertutup, terdapat lantai depot yang tidak rata dan pecah-pecah sehinga susah untuk dibersihkan serta terdapat depot dengan dinding bangunanya hanya menggunakan pagar besi sehinga sangat mudah masuknya debu dan hewan-hewan lain (12).

\section{Kondisi Hygiene Sanitasi Peralatan}

Tabel 2 menunjukan bahwa kondisi hygiene sanitasi depot air minum yang ada di Kecamatan Ratolindo dari segi aspek peralatan diketahui 0 depot air minum (0\%) tidak 
memenuhi syarat dan 11 depot depot air minum (100\%) memenuhi syarat. Sehinga hal tersebut dapat dikatan sesuai dengan PERMENKES RI No.43 tahun 2014. Hal ini dikarenakan seluruh depot air minum sudah memiliki peralatan yang begitu lengkap dan masih berfungsi dengan baik seperti telah mengukan perlatan sterilisasi berupa UV, ozon, ataupun sistem osmosis balik (reverse osmosis) yang dimana Proses desinfeksi bertujuan untuk menghilangkan mikroorganisme yang ada di dalam air baku sehingga air yang akan dikonsumsi sudah terbebas dari bakteri patogen (13).

\section{Kondisi Hygiene Sanitasi Penjamah}

Tabel 2 menunjukan bahwa kondisi hygiene sanitasi depot air minum dalam aspek penjamah yang ada di Kecamatan Ratolindo di dapatkan hasil bahwa dari segi aspek penjamah diketahui sebanyak 7 depot air minum $(63,6 \%)$ tidak memenuhi syarat dan 4 depot air minum $(36,4 \%)$ memenuhi syarat. Hal ini dikarenakan banyak pekerja atau penjamah depot air minum tidak menerapkan perilaku higiene sanitasi setiap melayani konsumen, seperti tidak mencuci tangan dengan sabun dan tidak menggunakan pakaian kerja yang bersih saat sedang melayani konsumen. Sehingga air minum yang diproduksi dapat berpotensi terkontaminasi oleh bakteri selama proses produksi (14).

\section{Kondisi Hygiene Sanitasi Air Minum}

Berdasarkan hasil wawancara, pada tabel 2 menunjukan kondisi hygiene sanitasi depot air minum yang ada di Kecamatan Ratolindo dari segi aspek air minum terdapat 1 depot air minum $(9,10 \%)$ tidak memenuhi syarat dan 10 depot air minum (10\%) memenuhi syarat. Hal ini dikarenakan terdapat depot air minum yang tidak melakukan pemeriksaan (fisik, kimia dan biologi) terhadap air minum yang diproduksi. Pemeriksaan air minum isi ulang sangat penting untuk dilakukan dengan tujuan untuk mendeteksi keberadaan patogen dalam air minum seperti coliform dan Escherichia coli. Bakteri coliform adalah bakteri yang digunakan sebagai indikator penentu kualitas air minum yang dihasilkan (15).

\section{KESIMPULAN DAN SARAN}

Hasil pemeriksaan kadar Escherichia colipada sampel air minum isi ulang menunjukkan bahwa seluruh depot memenuhi syarat sedangkan pemeriksaan kadar total bakteri coliform terdapat 3 depot air minum tidak memenuhi syarat kualitas air minum sesuai dengan permenkes no. 492/MENKES/PER/IV/2010. Perlu dilakukan penelitian lebih lanjut untuk mengetahui kualitas air minum isi ulang diseluruh DAM di Kabupaten Tojo Una-una baik dari segi fisik, kimia dan biologi. Perlu dilakukan pengawasan terhadap DAM oleh 
pemerintah khususnya dinas kesehatan untuk mengawasi depot yang tidak memeriksakan mutu produk air minum tetapi masih tetap beroperasi dan melayani konsumen.

\section{DAFTAR PUSTAKA}

1. Rosita N. Analisis Kualitas Air Minum Isi Ulang Beberapa Depot Air Minum Isi Ulang ( DAMIU ) di Tangerang Selatan. J Kim Val. 2014;4(2):134-41.

2. Hasriani MA and U. Deteksi Bakteri Coliform Dan Escherichia coli Pada Depot Air Minum Isi Ulang Di Kota Pasangkayu Kabupaten Mamuju Utara Sulawesi Barat. J Biocelebes. 2013;7(2).

3. Peraturan menteri kesehatan Nomor 492/MENKES/PER/IV. tentang pesyaratan kualitas air minum. 2010.

4. World Health Organization. Guidelines for drinking-water quality. 2017. p. 149.

5. Kementrian kesehatan RI. Profil Kesehatan Indonesia Tahun 2017. jakarta; 2018.

6. Dinas Kesehatan Kabupaten Tojo Una-Una. Profil Kesehatan Kabupaten Tojo Una-Una Tahun 2019. 2020.

7. Pinontoan roni $\mathrm{O}$ and sumampouw J.F. Dasar Kesehatan Lingkugan. Yogyakarta: Deepublish; 2019.

8. Dinas Kesehatan Provinsi Sulawesi Tenggah. Profil Kesehatan 2019. 2020.

9. Baharuddin A and L. Kualitas Air Minum Isi Ulang Pada Depot di Wilayah Kerja Puskesmas Dahlia Kota Makassar. Higiene. 2017;3(2):67.

10. Wulandari SA. . and AS. Higiene Dan Sanitasi Serta Kualitas Bakteriologis Damiu di Sekitar Universitas Negeri Semarang. Unnes J Public Heal. 2015;4(3):8-15.

11. Widyaningsih WS and NW. Analisis Total Bakteri Coliform di Perairan Muara Kali Wiso Jepara. Diponegoro J Maquares. 2016;5(3):157-64.

12. Yushananta, P. and mei. A. 2017. "Risiko Fotoreaktivasi Terhadap Kualitas Mikrobiologi Air Minum Isi Ulang.” Jurnal Kesehatan VIII(2):212-19.

13. Tominik Victoria I, Haiti .. M. and and Hutabarat Mustika Sari H. 2018. "Analisis Uji Kualitas Bakteriologis Air Minum Isi Ulang ( AMIU ) Menggunakan Metode MPN Pada Pengolahan Air Sistem Reverse Osmosis ( RO ) Dan Sistem Ultra Violet ( UV )." Jurnal Kesehatan Saelmakers Perdanaerdana 1(1):20-24.

14. Sampulawa, I and Tumanan, D. 2016. "Analisis Kualitas Air Minum Isi Ulang Yang Dijual Di Kecamatan Teluk Ambon." Jurnal ARIKA 10(1).

15. Sari, i. y. .. and all. 2018. "The Effectiveness of Ultraviolet, Ozonization and Reverse Osmosis as Disinfection Method in Drinking Water Refill Stations." Global Medical and Health Communication 6(38):193-201. 